\title{
LAW, CRIME, AND PUNISHMENT IN THE PEOPLE'S REPUBLIC OF CHINA: A COMPARATIVE INTRODUCTION TO THE CRIMINAL JUSTICE AND LEGAL SYSTEM OF THE PEOPLE'S REPUBLIC OF CHINA
}

\author{
Pamella A. Seay*
}

\section{Historical and CUltural Foundation of the ChINESE Systems}

To understand the current status of criminal justice in the People's Republic of China (P.R.C.), it is necessary to become acquainted with various influences on the creation of its laws. As in any developing country, the P.R.C. has been influenced by history, culture, and contemporary ideas.

The Chinese culture has existed for over 5000 years. The great philosopher Confucius introduced the concept of the importance of society over the individual. ${ }^{1}$ This simple idea has survived in Chinese culture and has influenced the evolution of Chinese law and criminal justice. Another legacy of Confucius is deference to ancestors, leaders, and members of the elite class. These teachings encouraged class differences, a pervasive theme throughout the Chinese imperial culture. ${ }^{2}$

Historically, China depended on the beneficence of its leaders in the application of law. Though laws may have been in writing, the application of them was left to the discretion of the individual leader - whether an emperor, a warlord, or a local governor. This discretionary approach became a "rule of the person," meaning that each person of authority could make a decision based on the prevailing beliefs, the most expedient choice, or the status of the person to be punished. This concept endured under Mao Zedong, despite an attempt to establish a classless or "uni-class society."3 The result was a wide range of vastly different punishments for what were often quite similar offenses. ${ }^{4}$

* J.D., University of South Carolina School of Law. Assistant Professor \& Program Coordinator, Criminal Justice Division, College of Professional Studies, Florida Gulf Coast University. Professor Seay is an attorney, licensed to practice law in South Carolina, Florida, and before the United States Supreme Court. Her internet homepage can be found at http://itech.fgcu.edu/justice/pseay.html. notes, 1997)

1. See generally THE ANALECTS OF CONFUCIUS (LUN YU) (Chichung Huang ed. \&

2. See id.

3. Carlos Wing-hung lo, China's Legal Awakening: legal Theory and CRIMINAL JUSTICE IN DENG's ERA 253 (1995).

4. RichaRd EVANS, DENG XIAOPING AND THE MAKING OF MODERN CHINA 136 (3d ed. rev., 1997). 


\section{II.THE RULE OF LAW IN THE PEOPLE'S REPUBLIC OF CHINA}

Contemporary changes began with the Chinese Revolution in 1911. Dr. Sun Yat Sen led the transition from an imperialist and feudal state, to a nationalist state, and then later to a communist state. It was Mao Zedong who declared the creation of the P.R.C. in Tiananmen Square, Beijing, in 1949. It was also Mao Zedong who, in effect, abolished all laws in $1957 .^{5}$ Following Mao's death in 1976, it was determined that the abolition of all laws was either a mistake, or at least no longer necessary, ${ }^{6}$ and in 1979 , Deng Xiao Ping authorized the creation of a written criminal code. ${ }^{7}$ A written constitution followed in $1982 .^{8}$ These documents and rules were slowly implemented and enforced, first in Beijing, then in other major cities, and finally in the remote provinces and villages. It is these documents and laws, this evolution to a "rule of law," which will be addressed here.

In a recent address, Chinese President Jiang Zemin emphasized the importance of the Rule of Law; he stated: "Ruling the country by law means ... that socialist democracy is gradually institutionalized and codified so that such institutions and laws will not change with changes in the leadership or changes in the views or focus of attention of any leader." ${ }^{10}$ With this idea in mind, the Chinese legal community has begun to work on establishing the best law and criminal justice system for the P.R.C.

To put the Chinese legal evolution into a historical context, the United States Constitution was adopted in 1789, nearly 200 years before the adoption of the Chinese constitution. The criminal codes of the various states, though constantly being reassessed and revised, have been adopted or acquired through years of research and trial and error. Many of the early states created their criminal codes by adopting the common law of England,

5. WING-HUNG LO, supra note 3 , at 10.

6. See id. at 1.

7. See id. at 261.

8. ZHONGHUA RENMIN GoNGHEguo XIANFA [Constitution] (1982) (P.R.C.). For an electronic version of the P.R.C. Constitution, see China - Constitution (last visited Nov. 16, 1998) <http://www.uni-wuerzburg.de/law/ch00000_html>.

9. The Chinese term for rule of law is fazhi. It should be noted that U.S. President Bill Clinton's and Chinese President Jiang Zemin's Joint Statements of 1997, as well as their joint statement made during President Clinton's state visit in June of 1998, focused on the institution and application of a rule of law. See The President's News Conference with President Jiang, 33 WeEkL Y COMP. PRES. DOC. 1673 (Oct. 29, 1997); The President's News Conference with President Jiang in Beijing, 34 WEEKLY COMP. PRES. DOC. 1245 (June 27, 1998).

10. Jiang Zemin, Hold High the Great Banner of Deng Xiaoping Theory for an AllRound Advancement of the Cause of Building Socialism with Chinese Characteristics into the 21st Century, in Selected Documents of THE 15TH CPC National Congress 1, 32 (1997). 
making the criminal codes even older than the states themselves. " China, with less than 20 years of experience in the enforcement and operation of its criminal laws, is likely to undergo a great deal of change as it adjusts to the practical application of the theories those laws espouse.

Citizens of the United States often take for granted the independence of their judiciary, though not all nations have followed the same path as the United States. The original Organic Law of the People's Courts of the P.R.C. read as follows: "The peoples courts shall administer justice independently, subject only to the law . . ." ${ }^{\prime 2}$ Recognizing the detrimental influence which individuals and groups once had on the administration of justice in the P.R.C., the National People's Congress (NPC) changed this article to more explicitly identify the restriction on influence. The new provision states: "The people's courts shall exercise judicial power independently, in accordance with the provisions of the law, and shall not be subject to interference by any administrative organ, public organization or individual." 13

The development of China's laws now involves a socialist democracy, or what the Chinese call "socialism with Chinese characteristics." 14 In paragraph seven of the Preamble to the Chinese Constitution, as amended on March 29, 1993, are these words: "Our country is in the primary stage of socialism. The basic task before the nation is the concentration of efforts on socialist modernization construction in accordance with the theory of building socialism with Chinese characteristics."15 Jiang Zemin, President of the P.R.C., reinforced this goal in a 1997 report by stating: "We should foster socialist ideology and ethics by basing ourselves on China's reality, carrying on the fine cultural traditions handed down from history and assimilating the advances of foreign culture."16

The dedication to socialism with Chinese characteristics is, as further noted in the Constitution's Preamble, subject to the leadership of the Communist Party. Paragraph ten of the preamble to the P.R.C. Constitution was revised in 1993. Paragraph ten reaffirms the predominance of the Party; it states that "[m]ulti-party cooperation and the political consultation system

11. For example, the Florida code states the following: "The common law of England in relation to crimes, except so far as the same relates to the modes and degrees of punishment, shall be of full force in this state where there is no existing provision by statute on the subject." FLA. STAT. ANN. \$775.01 (West 1992).

12. ORGANIC LAW OF THE PEOPLE'S COURTS OF THE PEOPLE'S REPUBLIC OF CHINA, art. 4 (1979) (P.R.C).

13. Decision of the Standing Committee of the National People's Congress, 6th National People's Cong., Regarding the Revision of the Organic law of the PEOPLE's COURTS OF THE PEOPLE's REPUBLIC OF CHINA, art. 4 (1983) (P.R.C.).

14. See WING-HUNG Lo, supra note 3, at 29-31, 258.

15. XIANFA, preamble, para. 7, amended by XIANFA, amend. art. 3 (1993).

16. Zemin, supra note 10 , at 20 . 
under the leadership of the Communist Party of China shall continue and develop for the extended future." 17 Communism and socialism both stress the importance of the society and the government, and the diminished importance of the individual; in a way this is a reversion to the Confucian belief in the importance of society over the individual, while distinctly rebelling against the Confucian focus on class. ${ }^{18}$

\section{STRUCTURE OF THE GOVERNMENT}

In 1979, the Legislative Sub-Committee of the Standing Committee of the NPC, led by Mrs. Wang Zhu Qian, was charged with the responsibility of overseeing the creation of the first P.R.C. criminal code. ${ }^{19}$ The resulting set of laws began the process of codification and constitutionalization of the legal system of the P.R.C. In establishing its legal system, the P.R.C. and the Communist Party created a unified system, with the NPC as the ultimate authority over all legal and governmental decision-making. ${ }^{20}$ This structure makes the NPC the overseer of the criminal justice and legal systems in China.

The United States chose to create a national system rich with checks and balances. In addition to the U.S. Constitution and federal government, each state has its own government, autonomous in many areas. Within the national and state governments, a separation of powers exists, spreading responsibility for different functions and duties into legislative, executive, and judicial branches. This method offers U.S. citizens the greatest amount of protection from the invasiveness of government. However, not all societies and governments agree with the United States' approach. China follows the unitary form, similar to that used in the constitutional monarchy of the United Kingdom. ${ }^{21}$ Because the P.R.C. has a unified system, it is important to have a basic understanding of all its operations, functions, and duties, particularly as they relate to criminal justice.

"The National People's Congress of the People's Republic of China is the highest organ of state power. Its permanent body is the Standing Committee of the National People's Congress."22 Each member of the NPC is elected for a term of five years, and the NPC meets once per year as convened by the Standing Committee. ${ }^{23}$ Since the NPC is not a full-time

17. XIANFA, preamble, para. 10, amended by XIANFA, amend. art. 3 (1993).

18. See generally THE ANALECTS OF CONFUCIUS, supra note 1.

19. Interview with Mrs. Wang Zhu Qian at the National People's Congress, Great Hall of the People, in Beijing, China (May 11, 1998).

20. See XIANFA, preamble, para. 11 \& arts. 57, 58, 62 (1982).

21. See XIANFA, preamble, para. 11 (1982).

22. XIANFA, art. 57 (1982).

23. See id. arts. 60,61 . 
legislature, it is the Standing Committee which conducts the daily affairs of the State throughout the year.

The Standing Committee is elected by the NPC and is composed of "the Chairman; the Vice-Chairmen; the Secretary-General; and the members." 24 The Chairman, the Vice-Chairmen, and the Secretary-General are the representatives of the Communist Party. Their election is controlled entirely by the Communist Party of China; therefore, the NPC has no authority to remove them from office. ${ }^{25}$ The Secretary-General of the Communist Party of China is presently the same person, Jiang Zemin, who serves as President of the P.R.C. This relationship has often existed in the P.R.C., creating a cross-over of power and influence between the two entities.

The Standing Committee exercises the duties of the NPC when the NPC is not in session, and it also interprets the Constitution and supervises its enforcement as part of its regular duties. ${ }^{26}$ The Standing Committee also has the power to annul those laws enacted by the NPC which "contravene the constitution or the statutes."27 Interestingly, the NPC has the power to "alter or annul inappropriate decisions of the Standing Committee[,]"28 thereby providing a small, though significant, balance of power between the two governing bodies.

From the preceding discussion, one can see a definite connection between the ruling NPC and the Chinese Communist Party. In the United States, the closest analogy might be the existence of the Democratic and Republican Parties and other minor parties. However, the extent of influence of these parties in the United States is, in a sense, advisory because there is no required connection between any party and the officials elected to serve.

\section{STRUCTURE OF THE COURT AND CRIMINAL JUSTICE SYSTEMS}

The Chinese criminal justice system was created through a unitary system of government, which greatly affects its functions. One function of the NPC is "to elect the President of the Supreme People's Court,"29 and "to elect the Procurator-General of the Supreme People's Procuratorate[,]" the prosecutorial branch of the government. ${ }^{30}$ The Standing Committee has the

24. Id. art. 65.

25. See Const. Of the Communist Party of The People's Republic of China , arts. 21,22 (1982).

26. XIANFA, art. 67 (1982).

27. Id. art. 67 , sec. 7 .

28. Id. art. 62 , sec. 11 .

29. Id. art. 62 , sec. 7 .

30. Id. art. 62 , sec. 8 . 
power to appoint or remove judges of the Supreme People's Court, ${ }^{31}$ and to appoint or remove Procurators. ${ }^{32}$ Again, a balance of power, almost a "check and balance" of its own, applies in this area of the Chinese justice system between the NPC and the Standing Committee.

"The people's courts of the People's Republic of China are the judicial organs of the state." 33 These courts are (1) the Supreme People's Court, (2) the High People's Courts of provinces, autonomous regions and municipalities, (3) the Intermediate People's Courts of prefectures, cities, leagues and autonomous prefectures, (4) the Primary People's Courts of counties, cities, banners and autonomous counties, and People's Tribunals set up by Primary People's Court, and (5) the courts of limited jurisdiction made up of (a) Maritime Courts, (b) Military Courts, and (c) Railway Courts. ${ }^{34}$

The Primary People's Courts are the trial courts, or what is referred to in the United States as a court of first instance. At the end of 1994, there were 3074 Primary People's Courts in China. ${ }^{35}$ An essential difference between U.S. and P.R.C. trial courts is the lack of a jury system in Chinese courts. The Chinese approach is designed similar to a German court, with "a collegial panel composed of three judges or of judges and people's assessors totalling three." ${ }^{36}$ In many instances, this panel will consist of a lead professional judge accompanied by two lay judges. If a case of first instance is held in a court other than the Primary People's Court, the panel may total between three and seven judges or a combination of three to seven judges and people's assessors. ${ }^{37}$ Ordinarily, the United States relies on a jury as the finder of fact and on a judge to instruct the jury on the application of the law to the facts. However, in China it is the responsibility of the panel to find the facts and apply the law. Questioning is led by attorneys, but may also be conducted by the judges. ${ }^{38}$

It must be noted that the jurisdiction of the Primary People's Court, as the court of first instance, extends over ordinary criminal cases committed by citizens of the P.R.C. ${ }^{39}$ However, crimes carrying a possible sentence of life imprisonment or the death penalty, and criminal cases in which the

31. See id. art. 67, sec. 11.

32. See id. art. 67, sec. 12.

33. Id. art. 123.

34. See Foreign AfF. Bureau of the Supreme People's Court of THE PEOPLE'S REPUBlic OF CHINA, THE PEOPLE's COURTS OF THE PEOPLE'S REPUBLIC OF CHINA 29 (1995) [hereinafter FOREIGN AFF. BUREAU].

35. See id. at 4.

36. Criminal Procedure law of the People's Republic of China [Crim. Proc.

L. P.R.C.] art. 147 (P.R.C.).

37. See id. art. 147.

38. See WING-hUNG Lo, supra note 3, at 265.

39. See CrIM. PROC. L. P.R.C art. 19. 
offenders are foreigners, are within the jurisdiction of the Intermediate People's Court. ${ }^{40}$ Additionally, a Primary People's Court may choose to defer jurisdiction to a higher court. ${ }^{41}$

In the trial court, an accused may choose to be represented by counsel, may undertake self-representation, or may choose to have a family member as a representative. ${ }^{42}$ In a country of over 1.4 billion people, finding a lawyer can be difficult and sometimes quite expensive. The attorneys fees quoted to defendants in the Chinese criminal system are equal to those of any comparable U.S. firm. ${ }^{43}$ However, when wages are sometimes less than $\$ 1000$ per year, a fee of over $\$ 100$ per hour would be insurmountable without assistance. Additionally, rural areas still suffer from a lack of attorneys, resulting in the unavailability of legal assistance. ${ }^{44}$ Indigent representation provided by the government, particularly in the urban areas, is becoming more frequent, since it is now required by law. ${ }^{45}$

All persons accused of a crime have a meaningful right to an interpreter or translator. ${ }^{46}$ Within the Constitution of the P.R.C., the right to an interpreter or translator is guaranteed to "any party," whether a Chinese citizen or not. ${ }^{47}$ In a nation of multiple languages and dialects, this right appears more of a necessity than a privilege. Therefore, the extension of this right to persons of all nationalities is very valuable. This is a critical distinction in the Chinese courts. The Constitution of the P.R.C. provides far more rights to citizens than to non-citizens. This fact is prominent throughout the constitution, where most rights are granted solely to "citizens" and not simply to "persons" or "parties."48 When such a right is granted to non-citizens as well, it is obviously looked upon as a requirement and not merely an accommodation.

The conduct of a trial necessarily includes the evaluation of evidence presented. Part one, chapter five of the Criminal Procedure Law of the P.R.C. spells out the applicable laws of evidence to be applied in any trial. Article 42 states that, "[a]ll facts that prove the true circumstances of a case shall be evidence[,]" and where evidence is presented, it "must be verified before it can be used as the basis for deciding cases." 49 With this caveat in

40. See id. art. 20.

41. See id. arts. 19, 23.

42. See id art. 32. 13, 1998).

43. Interview with attorneys from the law firm of King \& Wood in Beijing, China (May persons.

44. Currently, the P.R.C. reports an approximate ratio of one attorney for each 14,000

45. See Crim. Proc. L. P.R.C. art. 34.

46. See id. art. 9.

47. See XIANFA, art. 134 (1982).

48. See generally XIANFA (1982).

49. Crim. Proc. L. P.R.C. art. 42. 
mind, the laws identify seven categories of admissible evidence: "(1) material evidence and documentary evidence; (2) testimony of witnesses; (3) statements of victims; (4) statements and exculpations of criminal suspects or defendants; (5) expert conclusions; (6) records of inquests and examination; and (7) audio-visual materials." ${ }^{50}$ It is "strictly forbidden to extort confessions by torture and to collect evidence by threat, enticement, deceit or other unlawful means." 51 This provision is similar to the intent and interpretation of the U.S. Constitution's 4th and 5th Amendment prohibitions against unreasonable searches and seizures and self-incrimination. ${ }^{52}$ Additionally, similar to U.S. legal doctrine, an accused in a Chinese court cannot be convicted solely on his or her own statement of confession without corroborating evidence. ${ }^{53}$

\section{APPEALS AND PUNISHMENT}

As in any system of justice, there are two possible outcomes: guilty or not guilty. Generally, in the U.S. justice system, only the accused has the right to appeal a conviction. Furthermore, in an acquittal, a prosecutor's appeal would be considered double jeopardy. ${ }^{54}$ Upon the conclusion of a trial in China, however, both the accused and the state have the right of appeal. ${ }^{5 s}$ Under Chinese law and beliefs, this concept allows for justice to be served, no matter which side originally prevailed.

If the appeal is made by the accused or his or her representative, there can be no increase in the penalty or punishment, no matter what the finding of the appellate court. ${ }^{56}$ In the case of a protest by the procurator, there is no limitation on the imposition of sentence by the appellate court or, if remanded, by the trial court. ${ }^{57}$ Generally, a case will be completed - from trial through appeal - in six months. ${ }^{58}$

Depending on the type of crime committed, and sometimes the person who allegedly committed it, a criminal trial may begin at any of the four levels of the people's courts. ${ }^{59}$ The court which hears the appeal is based upon the court from which the appeal is made. An appeal from the Primary

50. Id.

51. Id. art. 43.

52. See U.S. ConsT. amends. IV, V.

53. See CRIM. Proc. L. P.R.C. art. 46.

54. See U.S. CONST. amend. V.

55. See CRIM. PROC. L. P.R.C. art. 180.

56. See id. art. 190.

57. See id.

58. Interview with Hon. Zhang Jun, Justice of the Supreme People's Court, in Beijing, China (May 15, 1998). Cf. CRIM. Proc. L. P.R.C. arts. 92, 125, 142, 207 (setting forth procedural provisions for time limits and discretion of prosecutions).

59. See CRIM. PROC. L. P.R.C. ch. 2. 
People's Court goes to the Intermediate People's Court of the appropriate prefecture, city, league, or autonomous region. Appeals from the Intermediate People's Court go to the Higher People's Court, and any appeal from the Higher People's Court goes to the Supreme People's Court. However, there is a one-appeal limit, no matter in which court the proceedings began. ${ }^{60}$ The time limit for an appeal of a judgment is ten days. ${ }^{61}$ Contrary to the U.S. system of appeals, in which the appellate court ordinarily reviews only the application of law, an appellate court of the P.R.C. "shall conduct a complete review of the facts determined and the application of law in the judgment of first instance and shall not be limited by the scope of appeal or protest. ${ }^{n 2}$ Similar to the decision-making authority of a U.S. appellate court, the People's Court of second instance may make its decision in any of the following manners: (1) reject the appeal and affirm the original judgment; (2) revise the judgment; or (3) rescind the original judgment and remand for retrial. ${ }^{63}$

Sentences in the People's Republic of China, in some respects, mirror the current forms of punishment in the United States. Restitution, probation, incarceration, and death are the primary modes of punishment assigned by Chinese courts. ${ }^{64}$ In China, there is no plea bargaining. ${ }^{65}$ Upon conviction, a sentence is imposed based on the "relevant provisions of the law and in light of the facts and nature of the crime, the circumstance under which the crime is committed and the degree of harmness [sic] done to the society."

In a case in which the person has been found guilty of a minor offense, the person may be exempted from criminal punishment and may, "in light of the specific circumstances surrounding the case, be reprimanded or ordered to make a statement of repentance or formal apology, or to compensate for the losses incurred," while also possibly being subjected to an administrative sanction. ${ }^{67}$ Persons convicted of crimes for which the sentence is three years or less may have their sentences suspended if "the offender has truly shown repentance and the granting of suspended sentence will do no harm to the society." 68 This method results in a kind of "sentence bargaining" upon conviction, rather than the American style of plea bargaining before a trial.

Encouraging repentance and accepting it towards a reduced sentence

60. See id. art. 10.

61. See id. art. 183.

62. Id. art. 186.

63. See id art. 189.

64. See, e.g., id. arts. 51, 199.

65. Interview with Hon. Zhang Jun, supra note 58.

66. FOREIGN AFF. BUREAU, supra note 34, at 17-18.

67. Id. at 18.

68. Id. 
reflects the Chinese philosophy of the importance of society over the individual. A criminal is of no use to society. A repentant criminal, one who has been reformed, can once again become a productive member of society. The primary purpose of punishment in China is reform. ${ }^{69}$ Reform is encouraged because it strengthens the community and creates a constructive society. Preference for reform is the foundation of the Chinese system of punishment, which includes the Lao gai and Lao jiao, prisons for reform and for re-education. ${ }^{70}$

Death as punishment is an option for a number of different crimes which are considered the most heinous in China. A unique aspect of the death penalty involves a capital punishment review. If the immediate execution of a criminal who has been sentenced to capital punishment is not deemed necessary, a two-year suspension of execution may be rendered at the time of adjudicating the capital punishment, and the criminal in question will be subjected to reform through labor and his performance will be watched for later decision. ${ }^{71}$ In such a situation, the death penalty is postponed for two years and an attempt at reform is made. At the conclusion of two years the criminal is re-evaluated to determine if sufficient reform has occurred. If reformation is observed, the death penalty will be set aside. ${ }^{72}$

Throughout this legal process, the participation of lawyers is widespread. The procurator is the Chinese representative in criminal proceedings. ${ }^{73}$ Under the auspices of the office of the Procurator-General, the procurator may lead the investigation, authorize an arrest, and conduct the prosecution of an accused. ${ }^{74}$ Also, the accused may choose to be represented by defense counsel. As previously noted, if the accused cannot afford a lawyer, one may be provided by the State.

\section{FUTURE OF THE LEGAL SYSTEM IN CHINA}

The concept of a "lawyer" in China is quite different from that found in the United States. A lawyer in the United States will generally have a four-year baccalaureate degree, a three-year law degree, and will have passed a bar exam. In China, no comparable preparation is required. A typical lawyer must at least be a high school graduate and may have taken some college law courses, or may have even earned a baccalaureate degree.

69. Interview with Mrs. Wang Zhu Qian, supra note 19. See also CrIM. Proc. L. P.R.C. art. 221.

70. For a brief definition of Lao gai and Lao jiao, see A GlosSARY OF POLITICAL TERMS OF THE PEOPLE's REPUBLIC OF CHINA 223-24 (Mary Lok trans., Kwok-sing Li 1995).

71. See Foreign AFF. BUREAU, supra note 34, at 15.

72. See id.

73. See Crim. Proc. L. P.R.C. art. 8.

74. See id. art. 3. 
The one prerequisite to the practice of law is to pass a civil service exam for the law. There are no mandated educational requirements for the practice of law. Similarly, judges need only take a civil service exam to enter the judiciary, though this exam differs from that taken by lawyers. ${ }^{75}$ Passage of the test is no guarantee that the applicant will become a judge. To become a judge, the applicant is also required to hold a college degree in law or to have legal training, and to have at least two years of employment. ${ }^{76}$ Final selection will still depend on the ultimate evaluation of the applicants to determine the most qualified. ${ }^{77}$

Most countries require some sort of specialized education before a person may practice law. As the P.R.C. has become more involved internationally, it first recognized the need for more lawyers, and second, acknowledged the possibility that its legal profession may need reform. President Jiang Zemin addressed the notion of improvement in the legal system by stating:

The smooth progress of the undertakings of the Party and the state inevitably requires that there must be laws to go by, that the laws must be observed and strictly enforced, and that law-breakers must be prosecuted. We shall strengthen legislation, improve its quality and form a socialist legal system with Chinese characteristics by the year 2010. To safeguard the dignity of the Constitution and other laws, we must see to it that all people are equal before the law and no individual nor organization shall have the privilege to overstep it. All government organs must perform their official duties according to law and guarantee the citizens' rights in real earnest by instituting a system of responsibility for law enforcement and a system of assessment and examination. We shall promote the reform of judicial affairs to ensure institutionally that the judicial organs are in a position to exercise adjudicative and procuratorial powers independently and fairly according to law, and establish a system for investigating and prosecuting anyone who is held responsible for unjust or misjudged cases. We shall improve the ranks of law-enforcing and judicial personnel. We shall educate the populace about the law to make them more aware of its importance. In particular, we shall enhance the leading cadres' awareness of the importance of the legal system and their ability

75. Interview with Hon. Zhang Jun, supra note 58; interview with Wu Mingde, Deputy Director of the Department of Lawyers, P.R.C. Ministry of Justice, in Beijing, China (May 12, 1998).

76. See ForeIgN AFF. BUREAU, supra note 34 , at 7.

77. See id. 
to perform their duties according to law. We must closely integrate the improvement of the legal system with the promotion of cultural and ethical progress and make sure that they advance synchronously. ${ }^{78}$

This acknowledgment has led to an examination of the role of the lawyer and a study of the preparation for the practice of law. Tsinghua University School of Law in Beijing ${ }^{79}$ recently hosted the China USA Conference on the Reform and Development of Legal Education. ${ }^{80}$ Law professors, judges, procurators, lawyers, and other interested parties met to discuss and evaluate different educational models for persons wishing to enter the legal profession. Discussions of methodology, purpose, and need dominated the conference. The dialogue which ensued is only the beginning of a thorough analysis of the legal profession and the possibility of creating a new national standard for legal education.

Exchanges, such as the legal education conference and student study tours, will continue to provide a means of exploration of new and different ideas. Whether or when reform occurs in the Chinese legal system will depend on the leaders and their commitment to improvement. Leaders such as President Jiang Zemin, Premier Zhu Rongji, and Mrs. Wang Zhu Qian have expressed their commitment to finding the best alternatives for the People's Republic of China and to working towards the implementation of these alternatives. Their keen perceptions, and those of others within the National People's Congress will be the keys to the development of Chinese justice in the new millennium.

78. Zemin, supra note 10 , at 34-35.

79. The internet homepage for Tsinghua University School of Law can be found at <http://www.tsinghua.edu.cn./docse/yxsz/flx/flx.htm/>.

80. Conference held May 8, 1998, at Tsinghua University School of Law, Beijing, China. 